\title{
Penegakan Hukum Tindak Pidana Narkotika ditinjau dari Perspektif Kriminologi
}

\author{
Agustinus Samosir \\ Universitas Bina Insan Lubuklinggau, Indonesia \\ Email : samosiragustinusmh@gmail.com
}

\begin{abstract}
Narcotics crime is a very serious human crime, has an extraordinary impact, especially on the young generation of a nation today. The purpose of this study was to analyze the enforcement of criminal law from a criminological perspective. The research method used is empirical juridical. The results of the study are that there are many victims of narcotics crime and systematic preventive efforts such as BNN Lubuklinggau City appoint 5,500 people as anti-drug activists who are spread in 72 villages and appoint consular in eight sub-districts to invite drug addicts to consciously participate in rehabilitation to suppress rehabilitation to suppress the number of drug addicts in Lubuklinggau City. Conclusion of efforts to prevent drug trafficking that is happening right now especially in the City of Lubuklinggau, infrastructure facilities need to be improved again with a more sophisticated detection quality. Counseling and prevention is always given as in government offices, in schools, and on campuses, the supervision of the police. The enforcement system provides maximum punishment.

Keywords: Law Enforcement; Narcotics; Criminology.
\end{abstract}

\begin{abstract}
Abstrak
Kejahatan Narkotika merupakan kejahatan kemanusian yang sangat berat, mempunyai dampak luar biasa, terutama pada generasi muda suatu bangsa saat ini. Tujuan dari penelitian ini untuk menganalisis penegakan hokum tindak pidana dari prespektif kriminologi. Metode penelitian yang digunakan adalah yuridis empiris. Hasil penelitian yaitu korban tindak pidana narkotika sudah banyak dan usaha-usaha pencegahan yang sistematis yaitu seperti BNN Kota Lubuklinggau menunjuk sebanyak 5.500 orang sebagai penggiat anti narkoba yang disebar di 72 kelurahan dan mengangkat konsuler di delapan kecamatan untuk mengajak pecandu narkoba untuk sadar mengikuti rehabilitasi untuk menekan jumlah pecandu narkoba di Kota Lubuklinggau. Simpulan upaya pencegahan terhadap peredaran Narkoba yang terjadi saat ini terlebih di Kota Lubuklinggau, sarana prasarana perlu di tingkatkan lagi dengan kualitas pendeteksi yang lebih canggih. Penyuluhan dan pencegahan selalu diberikan seperti di kantor-kantor pemerintahan, di sekolah, maupun di kampus-kampus tersebut, pengawasan dari pihak kepolisian. Sistem penegakannya memberikan hukuman yang maksimal.
\end{abstract}

Kata kunci : Penegakan Hukum, Narkotika, Kriminologi.

\section{PENDAHULUAN}

Dalam sejarahnya telah di kenal dalam peradaban bangsa-bangsa di dunia, Narkoba yang semula berguna untuk kesehatan sekarang perkembangan yang cepat, ternyata tidak hanya sebagai obat,tetapi merupakan suatu kesenangan, dan pada akhirnya melumpuhkan kemampuan urat saraf produktivitas kemanusiaan, yang berpotensi menurunkan harkat dan derajat hidup manusia dimana akal sehat tidak bekerja dengan baik. Peredaran secara ilegal yang sangat masif yang dilakukan oleh bandar terhadap seluruh jenis narkotika, pada akhirnya menjadi perhatian umat manusia yang beradab untuk mengatasi peredaran narkoba yang sangat membahayakan kehidupan bangsa, bahkan menjadi suatu nomenklatur baru dalam kejahatan, yakni kejahatan narkoba'.

Tiongkok, bahan sejenis GIL ini di kenal sebagai candu, dan dalam sejarahnya candu ini pernah menghancurkan Tiongkok sekitar 1840-an. Karena dipergunakan sebagai alat

\footnotetext{
${ }^{1}$ Mumuh Muhyiddin, Haris Budiman dan Diding Rahmat, Analisis terhadap Putusan Pengadilan Negeri Kuningan tentang Penyalahgunaan Narkotika. Logika : Journal of Multidisciplinary Studies, Vol. o9 Nomor or Juni 2018. 22-29.
} 
Logika : Journal of Multidisciplinary Studies, p-ISSN 2085-997X. e-ISSN 2715-4505.

Vol. 11 Nomor 02 Desember 2020. 87-94.

subversif oleh Inggris, sehingga dikenal dengan perang candu ( The Opium War). 1839-184, yang dimenangka oleh Inggris, setelah berhasil merusak mental lawannya melalui candu. ${ }^{2}$

Pada masa penjajahan Belanda, pemakaiannya obat candu sudah dilakukan larangan melalui perundang-undangan, yang pemakainnya dilakukan oleh kalangan menengah dan warga golongan Cina. Inggris dalam sejarahnya pernah menjual candu dalam jumlah yang besar-besaran kepada China, selanjutnya Amerika. Inggris dalam sejarahnya pernah menjual candu dalam jumlah besar kepada China, oleh maskapai Inggris, Britist East India Company (BEIC), dan Belanda, hingga berakhir dengan peristiwa perang candu tahun 18391942, yang berakhir dengan kekalahan Cina, dan berakibat dibukanya pelabuhan-pelabuhan sebagai pintu masuk candu hingga ke Sumatra dan Jawa melalui kongsi dagang VOC.

Industri narkotik sebenarnya adalah sebuah kosekuensi dari rentetan panjang revolusi politik yang berlangsung selama abad ke-19. Revolusi industri bukan merupakan berbagai perkembangan yang saling berkaitan, yang berpuncak pada transformasi dunia barat. Pabrik berkembang pesat berkat kemajuan teknologi, birokrasi ekonomi besar, yang muncul untuk memberikan pelayanan yang dibutuhkan oleh industri dan sistem ekonomi kapitalis. Harapan utama dari kapitalis adalah sebuah pasar bebas, tempat memperjualkan berbagai produk industri, sehingga dalam sistem ekonomi kapitalis inilah seseorang akan mendapatkan keuntungan sangat besar, sementara sebagian besar lainnya yang bekerja membanting tulang dalam jam kerja yang panjang menerima upah yang rendah. ${ }^{3}$

Istilah narkotika bukan lagi istilah asing bagi masyarakat, mengingat begitu banyaknya berita baik dari media cetak, maupun elektronik yang memberitakan tentang penggunaan narkotika dan psikotropika serta bagaimana korban dari berbagai kalangan dan usia berjatuhan akibat penggunaanya. Penggunaan narkotika dan psikotropika dapat mengakibatkan beberapa kelumpuhan psikis yang berakibat hilangnya kemampuan manusia berprestasi terhadap suatu hal. Hilangnya kemampuan kensentrasi dan mengambil keputusan ${ }^{4}$.

Alasan ekonomis penggunaan narkotik, karena sifat narkotik yang memabukan dan menjadikan setiap orang dapat melakukan kejahatan demi memenuhi kebutuhan atas zat adiktif yang telah di kontaminasi. Kejahatan narkotika, merupakan kejahatan kemanusiaan yang berat, yang mempunyai dampak luar biasa, terutama pada generasi muda suatu bangsa yang beradab. Kejahatan narkotika merupakan kejahatan lintas negara, karena penyebaran dan perdagangan gelapnya dilakukan dalam lintas negara. Dalam kaitannya dengan negara Indonesia, sebagai negara Hukum.

Dalam kaitannya dengan negara Indonesia, sebagai negara hukum, negara hukum yang dimaksud adalah negara yang menegakan supremasi hukum untuk menegakan kebenaran dan keadilan. Secara umum, dalam setiap negara yang menganut paham negara hukum terdapat tiga prinsip dasar, yaitu supremasi hukum (supremacy of law), kesetaraan dihadapan hukum (equality before the law), dan penegakan hukum dengan cara yang tidak bertentangan dengan hukum (due procces of law). Dalam penjabaran selanjutnya, pada setiap negara, hukum mempunyai ciri-ciri;jaminan perlindungan hak-hak asasi manusia,kekuasaan kehakiman atau pradilan yang merdeka, legalitas dalam arti hukum,

\footnotetext{
${ }^{2}$ Soetomo, 1995, Masalah Sosial, Pustaka Jaya, Jakarta.

${ }^{3}$ Andi Hamzah,1994, Asas-asas Hukum Pidana, Rineka Cipta, Bandung.

${ }^{4}$ Krisna Monita Sari, Penegakan Hukum terhadap Anggota Polri yang Melakukan Tindak Pidana Narkoba.

Logika : Journal of Multidisciplinary Studies, Vol. 10 Nomor o1 Juni 2019. 51-59.
} 
Logika : Journal of Multidisciplinary Studies, p-ISSN 2085-997X. e-ISSN 2715-4505.

Vol. 11 Nomor 02 Desember 2020. 87-94.

yaitu bahwa baik pemerintah/negara maupun warga negara dalam bertindak harus berdasar atas hukum. Hukum adalah himpunan petunjuk hidup, yang mengatur tata tertib dalam suatu masyarakat, dan seharusnya di taati oleh anggota masyarakat yang bersangkutan.

Kriteria bagi suatu negara yang modern adalah negara yang menerima dan menerapkan inovasi-inovasi baru demi kehidupan yang terus menerus lebih baik bagi rakyat. Kekuasaan pemerintah dalam negara modern yang berdasarkan hukum artinya dalam negara hukum pemerintah yang di bentuk secara demokratis hanya menyelenggarakan kekuasaan politiknya, terbatas pada kerangka mandat konstitusi. Hukum merupakan sesuatu yang berkenaan dengan kehidupan manusia. Hukum lahir dalam pergaulan dan perkembangan di tengah masyarakat. Serta berperan di dalam hubungan antar individu dan antar kelompok. Hukum mengejawantah dalam pergaulan itu, dalam bentuk ketentuan-ketentuan yang juga di namakan kaidah-kaidah atau norma-norma sosial. Narkotik dan Psikotropika sebagai masalah pada masyarakat majemuk dan berkaitan dengan dunia internasional, jelas memerlukan keperangkatan-keperangkatan hukum dalam bentuk undang-undang tertulis. Hukum narkotik merupakan hukum yang dapat menjangkau ke masa depan dan senantiasa mampu mengakomodir permasalahan narkotik dari masa ke masa 5 .

Secara subtansi bahwa penggunaan narkotika dan psikotropika adalah merupakan konsep dari pada hukum kesehatan menurut Undang-Undang Kesehatan Nomor 36 Tahun 2009, yang menganggap penggunaan narkotik dan psikotropika di tempatkan atau pada sasaran terhadap ilmu kesehatan dalam bidang kedokteran, namun dengan ketidakwaspadaan terhadap penyalahgunaan maka pemerintah dalam hal ini memberikan suatu batasan hukum terhadap penggunaan dengan mengeluarkan Undang-Undang Nomor 35 tahun 2009 tentang Narkotik dan Undang- Undang Nomor 5 Tahun 1997 tentang Psikotropika. ${ }^{6}$

Dengan adanya Undang-Undang Narkotika dan Psikotropika, maka sebagai hukum yang mengatur tentang tertib dalam masyarakat. Hukum dilihat sebagai suatu pertumbuhan dinamis, didasarkan pada suatu keyakinan bahwa hukum itu terjadi sebagai suatu yang di rencanakan, dari situasi tertentu menuju pada suatu tujuan yang tidak yuridis, karenanya faktor diluar hukumlah yang memelihara berlangsungnya proses pertumbuhan dinamis dari hukum itu. Penegakan hukum kejahatan narkotika dan psikotropika, dilakukan dengan sangat gencar, tetapi organisasi mafianya juga tersusun dengan rapi, yang memungkin terlibatnya penegak hukum atau mantan penegak hukum. Sehingga, sangat sulit dilakukan pemberantasannya. Jumlah narkotika dan psikotropika, semakin banyak, dan para pemakainnya juga terus bertambah. Tidak hanya dari kalangan keluarga yang tidak bahagia, tetapi juga telah menjalar pada masyarakat ekonomi menengah dan kalangan yang berbahagia. Masuk jalur norkotika dan psikotropika di kenal melalui segi tiga emas (golden triangle), yang terletak antara thailand,Myanmar, dan Laos. Di Indonesia, peredaran narkotik dilakukan dengan berbagai cara, dan cara-cara tersebut sudah mendekati cara mafia internasional.

Walaupun pencegahan narkotika dan psikotropik berdasarkan perundang-undangan sudah sangat ketat dengan penggunaan penyadapan, pembelian terselubung, dan

\footnotetext{
${ }^{5}$ Wisnu Gita Prapanca, Penegakan Hukum terhadap Jaksa yang Melakukan Tindak Pidana Narkotika. Logika : Journal of Multidisciplinary Studies. Vol. 1o Nomor o1 Juni 2019. 6o-68.

${ }^{6}$ Moh. Taufik Makaro,cs.2005, Tindak Pidana Narkotika,Bogor: Galia Indonesia.
} 
Logika : Journal of Multidisciplinary Studies, p-ISSN 2085-997X. e-ISSN 2715-4505.

Vol. 11 Nomor 02 Desember 2020. 87-94.

pengawasan terhadap penyerahan barang yang memungkinkan kemudahan proses pembuktian, tetapi masih saja terbuka jalan peredaran gelap dan pemakaiannya yang justru berkembang di hampir lembaga institusi hingga para penegak hukum di berbagai tingkatannya. Inilah yang menjadi dasar pemikiran secara teoretis untuk mengkaji tentang Peredaran Narkotika di Kota Lubuklinggau di tinjau dari Perspektif Kriminologi

\section{METODE PENELITIAN}

Metode penelitian hukum, menurut Soerjono Soekanto adalah suatu kegiatan ilmiah, yang didasarkan pada metode, sistematika dan pemikiran tertentu, yang bertujuan mempelajari satu atau beberapa gejala hukum tertentu, dengan menganalisanya ${ }^{7}$. Metode penelitian yang digunakan adalah penelitian kepustakaan (library research) yaitu data sekunder yang diperoleh dari UUD 1945, Undang-Undang, hasil studi pustaka buku-buku, jurnal ilmiah, skripsi, dan referensi yang relevan.

\section{HASIL DAN PEMBAHASAN}

Kriminologi sebagai ilmu sosial yang mempersoalkan segala macam gejala sosial beserta ruang lingkup gejolak arti itu sendiri sehingga para ahli kriminologi memberikan pengertian menurut disiplin ilmunya masing-masing. Kriminologi dapat diartikan sebagai ilmu pengetahuan yang mempelajari tentang kejahatan. Menurut Andi Zainal, bahwa kriminologi adalah ilmu pengetahuan yang mempelajari faktor-faktor penyebab kejahatan, dan cara bagaimana menanggulanginya. Bonger menyatakan kriminologi adalah ilmu pengetahuan yang bertujuan menyelidiki gejala-gejala kejahatan seluas-luasnya. Mabel Elliot, mendefinisikan bahwa kriminologi adalah kejahatan keseluruhan kelakuan yang dilarang dan dipidana oleh negara sebagaimana dirumuskan dalam undang-undang. Selanjutnya, secara etimologis kriminologis berasal dari kata "crime" yang artinya kejahatan, sedangkan "logos" yang artinya ilmu pengetahuan. Secara lengkap, kriminologi dapat diartikan sebagai ilmu pengetahuan yang mempelajari tentang kejahatan.

Berdasarkan pengertian tersebut di atas, maka kriminologi mengandung pengertian yang sangat luas. Di katakan demikian karena didalam mempelajari kejahatan tidak lepas dari berbagai pengaruh sudut pandang. Ada yang memandang kriminologi dari sudut latar belakang timbulnya kejahatan, dan ada pula yang memandang kriminologi sudut prilaku di dalam masyarakat. Oleh sebab itu, peneliti merinci pengertian kriminologi menurut para ahli, dengan maksud untuk mempermudah dalam memahami dan membedakan pengertian tiap-tiap bagiannya. Teori-teori Tentang Penyebab Timbulnya Kejahatan, Ralf Dahrendof juga mengembangkan teori konflik berdasarkan perspektif, bahwa:

1. Masyarakat senantiasa berada dalam proses perubahan yang di tandai oleh pertentangan yang terus menerus diantara unsu-unsurnya

2. Teori konflik melihat bahwa setiap element memberikan sumbangan terhadap disetegrasi sosial.

3. Teori konflik juga menilai ketentuan yang terdapat didalam masyarakat itu hanyalah disebabkan adanya tindakan pemaksaan kekuasaan dari atas oleh golongan yang berkuasa.

\footnotetext{
${ }^{7}$ Diding Rahmat, 2016, "Eksistensi Lembaga Bantuan Hukum (LBH) Cirebon dalam Pendampingan Perkara Pidana di Pengadilan Negeri Cirebon”, Jurnal Ilmu Hukum Vol. 3 No. 1 Januari 2016, Kuningan: FH Uniku, hlm. 1-13.
} 
Logika : Journal of Multidisciplinary Studies, p-ISSN 2085-997X. e-ISSN 2715-4505.

Vol. 11 Nomor 02 Desember 2020. 87-94.

Teori konflik juga menilai ketentuan yang terdapat didalam masyarakat itu hanyalah disebabkan adanya tindakan pemaksaan kekuasaan dari atas oleh golongan yang berkuasa. Untuk lebih melengkapi teori-teori tentang sebab musabab kejahatan akan dipaparkan teori lain tentang hal tersebut. Teori yang dimaksud adalah teori penyimpangan budaya "cultural deviance Theories " dalam teori ini terdiri atas tiga teori utama yaitu:

1. Social disorganozation;

2. Diffential asscaition;

3. Culture conflict.

Socialdisorganozationtheory memfokuskan pada perkembangan area-area yang angka kejahatannya tinggi yang berkaitan dengan disintegrasi nilai-nilai konfensional yang di sebabkan oleh industrialisasi yang cepat, peningkatan imigrasi dan urbanisasi. Dari teori di atas menyatakan bahwa penjahat dan delinquent pada kenyataanya menyesuaikan diri bukan pada nilai konfensional melainkan pada norma-norma yang menyimpang dari nilai kelompok dominan dalam masyarakat. ${ }^{8}$ Konsep Tindak Pidana, Tindak Pidana (delik) berasal dari istilah Belanda yaitu "Strafbaarfeit", dimana Strafbaarfeit tersebut dapat terjemahkan dalam beberapa istilah di antaranya: peristiwa pidana, perbuatan pidana, perbuatan yang dapat di hukum,pelanggaran pidana, dan delict. Istilah-istilah di atas dapat diarik kesimpulan, bahwa pada hakekatnya istilah yang paling tepat adalah istilah "delik" yang berasal bahasa latin "delictum" dan "delicta". Van Hamel merumuskan delik sebagai berikut: "delik adalah kelakuan manusia yang dirumuskan dalam undang-undang melawan hukum yang patut dipidana yang dilakukan oleh kesalahan. Seorang pakar hukum P.A.F Lamintang, istilah strafbaarfeit diterjemahkan sebagai tindak pidana, beliau merumuskan sebagai berikut : Tindak Pidana adalah tindakan melanggar hukum yang dilakukan dengan sengaja oleh seseorang yang dapat pertanggungjawabkan atas tindakannya sebagai suatu tindakan yang dapat di hukum. Kriminalisasi Kejahatan Narkotika, Kejahatan narkotika seperti bom waktu karena perkembangannya dari waktu ke waktu semakin menunjukan pemakiannya yang sangat pesat. Bukan hanya pemakaiannya yang sangat memprihatinkan dan membahayakan seluruh kalangan umat manusia, tetapi juga industri yang dijalankan secara gelap terhadap narkotika justru yang terbesar didunia dilakukan di Indonesia. Kejahatan narkotika adalah kejahatan kemanusiaan yang sangat luar biasa yang bisa menghancurkan segala sendi kehidupan seluruh bangsa, juga mempunyai dimensi kejahatan yang lebih besar yang dapat ditimbulkan di Indonesia.

Berdampak pada perekonomian nasional, pengingkaran terhadap nilai-nilai kemanusiaan, dan dapat berakibat fatal terhadap kerusakan akhlak dan moral putra dan putri penerus bangsa yang timbulkan oleh bahaya narkotika saat ini yang harus kita samasama lawan peredaran di Indonesia. Dalam sejarahnya, perang terhadap narkotika dapat mengakibatkan hubungan antar negara menjadi terganggu. Karenanya, kejahatan ini harus mendapatkan perhatian yang sistematik dan perhatian khusus setiap negara untuk memutus mata rantai kejahatan narkotika di suatu negara. Terlebih Pemerintah Kota Lubukliggau bekerjasama jajaran yang ada di BNN Kota Lubuklinggau menunjuk sebanyak 5.500 orang sebagai penggiat anti narkoba yang disebar di 72 kelurahan dan mengangkat konsuler di delapan kecamatan untuk mengajak pecandu narkoba untuk sadar mengikuti rehabilitasi untuk menekan jumlah pecandu narkoba di Kota Lubuklinggau. Plt Kepala BNN

${ }^{8}$ Lamintang, 1984, Delik-delik Khusus, Tarsito,Bandung. 
Logika : Journal of Multidisciplinary Studies, p-ISSN 2085-997X. e-ISSN 2715-4505.

Vol. 11 Nomor 02 Desember 2020. 87-94.

Kota Lubuklinggau memberikan data mengenai pencapain dalam penaganan peredaran Narkoba di Kota Lubuklinggau. Data capaian 2018-2019. Tabel.1

Tabel 1. Data capaian 2018-2019.

\begin{tabular}{|c|c|c|c|}
\hline Tahun & Bulan & Pasokan & Permintaan \\
\hline \multirow[t]{11}{*}{2018} & Januari & 1 & 17 \\
\hline & Februari & 1 & 9 \\
\hline & Maret & 3 & 2 \\
\hline & April & 0 & 5 \\
\hline & Mei & 1 & 9 \\
\hline & Juni & 0 & 2 \\
\hline & Juli & 1 & 2 \\
\hline & Agustus & 2 & 2 \\
\hline & September & 1 & 12 \\
\hline & Oktober & 4 & 8 \\
\hline & November & 2 & 5 \\
\hline \multirow[t]{5}{*}{2019} & Desember & o & 1 \\
\hline & Januari & o & 9 \\
\hline & Februari & 0 & 15 \\
\hline & Maret & 0 & 3 \\
\hline & April & o & 10 \\
\hline
\end{tabular}

Sumber BNN Kota Lubunglingau

Tabel 2. Angka Prevalansi Penyalahgunaan Narkoba

\begin{tabular}{ccc}
\hline Tahun & Pernah Pakai & Pakai Setahun Terakhir \\
\hline 2015 & $8.10 \%$ & $5.20 \%$ \\
\hline 2016 & $7.89 \%$ & $5.10 \%$ \\
\hline 2017 & $4.30 \%$ & $2.90 \%$ \\
\hline 2018 & $3.80 \%$ & $1.90 \%$ \\
\hline
\end{tabular}

Sumber BNN Kota Lubunglingau

Tabel.3 Data penyalahgunaan narkoba menurut usia

\begin{tabular}{llc}
\hline \multicolumn{1}{c}{ No. } & \multicolumn{1}{c}{ Usia } & Jumlah \\
\hline 1. & $16-20$ Tahun & 110 \\
\hline 2. & $21-25$ Tahun & 229 \\
\hline 3. & $26-30$ Tahun & 353 \\
\hline 4. & $31-35$ Tahun & 244 \\
\hline 5. & 36-40 Tahun & 102 \\
\hline 6. & 41-45 Tahun & 39 \\
\hline 7. & $>45$ Tahun & 11 \\
\hline
\end{tabular}

Sumber BNN Kota Lubunglingau

Ketika yang melakukan dan menjadi korban anak-anak yang masih remaja dalam tahap proses pertumbuhan dan Dewasa yang produktif, maka dampak sosial yang sangat besar yang akan timbulkan dari kejahatan narkotika yaitu kehancuran masa depan, fisik maupun mental yang teramat panjang untuk memulihkan mereka dari bahaya narkotika. Namun, kompleksitas dalam penanggulanggannya menimbulkan masalah yang sangat 
Logika : Journal of Multidisciplinary Studies, p-ISSN 2085-997X. e-ISSN 2715-4505.

Vol. 11 Nomor 02 Desember 2020. 87-94.

rumit. Berdasarkan Jenis Narkoba yang digunakan yang ada di Kota Lubuklinggau yaitu didominasi oleh ganja dan sabu. Undang-Undang Narkotika dan Psikotropika, sebagai hukum yang mengatur tentang tertib dalam masyarakat. Hukum dilihat sebagai suatu pertumbuhan yang dinamis, didasarkan pada suatu keyakinan bahwa hukum itu terjadi sebagai suatu yang direncanakan, dari situasi tertentu menju pada suatu tujuan yang akan dicapai. Hukum sebagai alat untuk mencapai yujuan yuridis, karenanya faktor diluar hukumlah yang memelihara berlangsungnya proses pertumbuhan dinamis dari hukum itu.

Penegakan kejahatan Narkotika, dilakukan dengan sangat gencar, tegas tanpa pandang bulu dalam penegakannya, untuk memutus mata rantai peredaran narkotika karena organisasi mafianya juga tersusun dengan rapi, yang memungkinkan terlibatnya penegak hukum atau mantan penegak hukum. Sehingga, membutuhkan cara yang sangat sulit untuk dilakukan memutus mata rantai pemberantasannya. Jumlah Narkotika yang beredar semakin banyak, dan para pemakainya juga terus bertambah, semua lapisan masyarakat semua kena tidak hanya dari kalangan keluarga yang tidak bahagia, tetapi juga telah menjalar pada masyarakat ekonomi menengah dan kalangan yang berbahagia semua terkena akan bahayanya peredaran narkotika saat ini. Masuknya jalur Narkotika dikenal melalui segi tiga emas (goldentringle), yang terletak antara Thailand, Myanmar, Laos. Di Indonesia peredaran narkotika semua cara dilakukan guna mengedarkan narkotika, dan cara-cara tersebut sudah mendekati cara mafiah internasional.

\section{SIMPULAN}

Pencegahan terhadap peredaran Narkoba yang terjadi saat ini terlebih di Kota Lubuklinggau, sarana prasarana perlu di tingkatkan lagi dengan kualitas pendeteksi yang lebih canggih. Penyuluhan dan pencegahan selalu diberikan seperti di kantor-kantor pemerintahan, di sekolah, maupun di kampus-kampus tersebut, pengawasan dari pihak kepolisian. Sistem penegakannya memberikan hukuman yang maksimal.

\section{SARAN}

Kepada pemerintah daerah bahwa penegakan hukum untuk narkotika ini harus mendapat dukungan pemerintah, yaitu hukum yang diterapkan harus disosiialisasikan dulu kepada masyarakat luas, penegakan hukum harus tegas tanpa pandang bulu, partisipasi masyarakat dalam pencegahan dan penegakan hukum, sarana dan prasarana yang masih perlu dukungan dan peran pemerintah.

\section{DAFTAR PUSTAKA}

Andi Hamzah,1994, Asas-asas Hukum Pidana, Rineka Cipta, Bandung.

Diding Rahmat, 2016, "Eksistensi Lembaga Bantuan Hukum (LBH) Cirebon dalam Pendampingan Perkara Pidana di Pengadilan Negeri Cirebon”, Jurnal Ilmu Hukum Vol. 3 No. 1 Januari 2016, Kuningan: FH Uniku, hlm. 1-13.

Krisna Monita Sari, Penegakan Hukum terhadap Anggota Polri yang Melakukan Tindak Pidana Narkoba. Logika : Journal of Multidisciplinary Studies, Vol. 10 Nomor o1 Juni 2019. 51-59.

Lamintang, 1984, Delik-delik Khusus, Tarsito,Bandung. 
Logika : Journal of Multidisciplinary Studies, p-ISSN 2085-997X. e-ISSN 2715-4505.

Vol. 11 Nomor 02 Desember 2020. 87-94.

Mardani, 2008, Penyalahgunaan Narkoba dalam Perspektif Hukum Islam dan Hukum Pidana Nasional,Jakarta,PT Raja Grafindo

Moh. Taufik Makaro,cs.2005, Tindak Pidana Narkotika,Bogor: Galia Indonesia.

Mumuh Muhyiddin, Haris Budiman dan Diding Rahmat, Analisis terhadap Putusan Pengadilan Negeri Kuningan tentang Penyalahgunaan Narkotika. Logika : Journal of Multidisciplinary Studies, Vol. o9 Nomor o1 Juni 2018. 22-29.

Soetomo, 1995, Masalah Sosial, Pustaka Jaya, Jakarta.

Wisnu Gita Prapanca, Penegakan Hukum terhadap Jaksa yang Melakukan Tindak Pidana Narkotika. Logika : Journal of Multidisciplinary Studies. Vol. 1o Nomor o1 Juni 2019. 6o-68.

Undang-Undang Nomor 35 tahun 2009 tentang Narkotika 